\title{
Translocations affecting human immunoglobulin heavy chain locus
}

\author{
I. V. Sklyar ${ }^{1,2,3}$, O. V. Iarovaia ${ }^{2,3}$, M. Lipinski ${ }^{1,3}$, Y. S. Vassetzky ${ }^{2,3}$ \\ ${ }^{1}$ CNRS UMR8126, Paris-Sud University, Gustave Roussy Institute \\ 114, rue Edouard Vaillant, 94805 Villejuif Cedex-France \\ ${ }^{2}$ Institute of Gene Biology, Russian Academy of Sciences \\ 34/5, Vavilova Str., Moscow, Russian Federation, 119334 \\ ${ }^{3}$ LIA 1066 French-Russian Joint Cancer Research Laboratory \\ Villejuif, France-Moscow, Russian Federation \\ vassetzky@igr.fr
}

\begin{abstract}
Translocations involving human immunoglobulin heavy chain (IGH) locus are implicated in different leukaemias and lymphomas, including multiple myeloma, mantle cell lymphoma, Burkitt's lymphoma and diffuse large B cell lymphoma. We have analysed published data and identified eleven breakpoint cluster regions (bcr) related to these cancers within the IgH locus. These $\sim 1 \mathrm{kbp}$ bcrs are specific for one or several types of blood cancer. Our findings could help devise PCR-based assays to detect cancer-related translocations, to identify the mechanisms of translocations and to help in the research of potential translocation partners of the immunoglobulin locus at different stages of B-cell differentiation.
\end{abstract}

Keywords: translocation, human immunoglobulin heavy chain, oncogenesis, lymphoma, leukaemia, B-cell differentiation.

Introduction. One hundred years ago German cytologist Theodor Boveri proposed that translocations may give rise to cancer [1]. Translocations are the transfer of a piece of one chromosome to a non-homologous chromosome or to a new site on the same chromosome. Indeed, translocations are associated with many cancers, including sarcomas, lymphomas, leukaemias etc. [2]. These translocations involve specific loci and genes. Translocations may place genes in new linkage relationships, produce chimeric genes and could generate chromosomes without normal pairs [3]. Human immunoglobulin heavy chain locus is one of the most frequent partners in translocations leading to leukaemias and lymphomas. Here we shall consider translocations involving this locus, its potential partners and mechanisms leading to translocations and lymphomagenesis.

(C) Institute of Molecular Biology and Genetics, NAS of Ukraine, 2014
Mechanisms of translocations. Translocations result from erroneous double-strand breaks (DSB) repair in DNA [4]. The DSBs appear in physiological and pathological processes and under the influence of external conditions such as oxidative stress and ionizing radiation (for review see [5]). DSBs also occur in immunoglobulin genes during lymphoid cell maturation [6].

The appearance of DSBs activates the cellular DNA repair machinery that catalyses the joining of broken chromosome ends [7] that can occur either by homologous recombination (HR) or by non-homologous end joining (NHEJ). NHEJ joins the ends of the broken chromosome; this repair mechanism is error-prone and can result in variety of rearrangements: deletions, duplications, and inversions. Furthermore, translocations may occur when the broken ends of two non-homologous chromosomes are joined together.

Chromosomal translocations may result in tree possible scenarios: (1) deregulation of important genes, and 
particularly proto-oncogenes and tumour suppressor genes crucial for regulation of most cellular processes [8-10]. This happens either by juxtaposition of oncogenes to a transcription control element of another gene on a different chromosome, thereby leading to an abnormal expression of the translocated gene or by relocalization of the translocated region in the nuclear space $[11,12]$; (2) the translocation may result in the formation of a unique fusion gene, which in turn codes for an activated form of the protein that affects the normal cellular physiology; (3) some translocations, particularly non-reciprocal ones, may lead to changes in gene dosage, $i$. e. loss of tumour suppressor genes or duplication of oncogenes.

Translocations in lymphomas and leukaemias. Vast majority of lymphomas and leukaemias are caused by translocations. The elevated frequency of translocations in this case is due to high amount of DSBs at immunoglobulin genes generated by RAG1/2 during $\mathrm{V}(\mathrm{D}) \mathrm{J}$ recombination, T-cell receptor (TCR) gene rearrangement and activation-induced (DNA-cytosine) deaminase (AID) during somatic hypermutation and class switch recombination essential for creation of antigen repertory [6].

$\mathrm{V}(\mathrm{D}) \mathrm{J}$ recombination is a physiological process during which variable $(\mathrm{V})$, diversity $(\mathrm{D})$ and joining $(\mathrm{J})$ segments of immunoglobulin (Ig) or T-cell receptor (TCR) genes are rearranged and lead to great diversity of the Ig/TCR repertoire. This process is mediated by lymphocyte-specific endonucleases (RAG1, RAG2) which cut the regional V(D)J genes at flanking recombination signal sequences (RSS) consisting of specific highly conserved heptamer and nonamer sequences with a non-conserved spacer (12 or 23 nucleotides) inbetween $[13,14]$. Subsequently, the coding segments are joined using the classical non-homologous end-joining (NHEJ) pathway. Translocations during V(D)Jrecombination may lead to different cancers, e. g. multiple myeloma, mantle cell lymphoma, or childhood acute lymphoblastic leukemia (see below).

Somatic hypermutation and class switch recombination in the Immunoglobulin heavy chain locus ( $\operatorname{IgH})$ also play a key role in generating antibody diversity. Activation-induced (DNA-cytosine) deaminase [13, $15,16]$ participates in both processes. AID deaminates the cytosines present in single-stranded regions (during transcription or formation of R-loops) into uracil, which results in a mismatch. This can be further processed by uracil N-glycosylase/AP endonuclease, finally leading to either a mutation or a DSB $[14,17-20]$. The DSB generated is an intermediate for class switching and, therefore, if unrepaired, can be a suitable candidate for illegitimate joining. This is supported by recent studies, where it was demonstrated that the breaks in the $c-m y c$ gene locus during $\mathrm{t}(8 ; 14)$ translocation, characteristic of Burkitt's lymphoma, are induced by AID 10 [21-24]. The $c$-myc region has also been suggested to form G-loop structures on plasmid DNA, which can be bound by AID [25].

Translocations in the human immunoglobulin heavy chain locus. Active recombination occurring at the IgH and TCR loci makes them ideal partners for translocations; indeed, many cancers are linked to translocation in these loci (for review see [3]). In the present review we shall concentrate on translocations involving the IgH located in the subtelomeric region of the $14 \mathrm{q}$ chromosome at $14 \mathrm{q} 32.33$. The IgH spans $1250 \mathrm{ki}-$ lobases (kb). It consists of 4 parts: V (variable), D (diversity), J (joining), and C (constant). Each part contains a significant amount of genes, $129 \mathrm{IGHV}$ genes, 27 IGHD segments belonging to 7 subgroups, 9 IGHJ segments, and 11 IGHC genes [21]. These genes are the subjects to $\mathrm{V}(\mathrm{D}) \mathrm{J}$-recombination in bone marrow, and class-switch recombination in germinal centers.

Translocations in the IgH locus during the B-cell differentiation could involve different parts of the locus and lead to a different type of cancers. Below we shall concentrate on the translocation hotspots also called breakpoint cluster regions (bcrs) within the IgH region. Translocations in the IgH locus have been extensively characterized [26-52]; reviewed in [36, 52, 53], but so far, no comprehensive analysis of the localization of bcrs in this locus has been done.

Breakpoint and translocation clusters were identified in several lymphomas; their average size is $\sim 1 \mathrm{kbp}$ [54]. We have identified bcrs involved in translocations with different partners leading to lymphoid malignancies. We have analysed published data to identify the breakpoint regions in cancers with translocations involving the IgH locus (Mantle cell lymphoma, Burkitt's lymphoma, diffuse large B-cell lymphoma, and multiple myeloma). We have found 195 individual transloca- 
Breakpoint cluster regions in the human immunoglobulin heavy chain gene locus

\begin{tabular}{|c|c|c|c|c|c|}
\hline $\begin{array}{l}\text { Breakpoint } \\
\text { cluster region }\end{array}$ & Type of cancer & Number of cases & $\mathrm{IgH}$ region & $b c r$ size, bp & $\begin{array}{l}\text { Coordinates on } \\
\text { IgH map (ref) }\end{array}$ \\
\hline$b c r 1$ & Mantle cell lymphoma & 3 & IGHD5-18 & 978 & $929160-930137$ \\
\hline \multirow[t]{2}{*}{$b c r 2$} & Mantle cell lymphoma, & 18 & IGH J4-J5-J6 & 1060 & $959075-960135$ \\
\hline & Burkitt's lymphoma & 5 & & & \\
\hline$b c r 3$ & Mantle cell lymphoma & 3 & IGH J2-J3-J4 & 1184 & $957695-958878$ \\
\hline \multirow[t]{2}{*}{$b c r 4$} & Mantle cell lymphoma, & 6 & IGHM & 995 & $962031-963025$ \\
\hline & Burkitt's lymphoma & 7 & & & \\
\hline \multirow[t]{2}{*}{$b c r 5$} & Mantle cell lymphoma, & 3 & IGHM & 1083 & $963016-964099$ \\
\hline & Burkitt's lymphoma & 10 & & & \\
\hline \multirow[t]{2}{*}{ bcr6 } & Mantle cell lymphoma, & 2 & IGHM & 1340 & $964148-965487$ \\
\hline & Burkitt's lymphoma & 5 & & & \\
\hline \multirow[t]{3}{*}{$b c r 7$} & Diffuse large B-cell lymphoma, & 2 & IGHG3 & 731 & $1049447-1050177$ \\
\hline & Multiple myeloma, & 2 & & & \\
\hline & Burkitt's lymphoma & 4 & & & \\
\hline \multirow[t]{2}{*}{ bcr8 } & Multiple myeloma, & 5 & IGHG1 & 1087 & $1077375-1078461$ \\
\hline & Burkitt's lymphoma & 10 & & & \\
\hline$b c r 9$ & Burkitt's lymphoma & 17 & IGHA1 & 1278 & 1111692-1112969 \\
\hline \multirow[t]{2}{*}{ bcr 10} & Multiple myeloma, & 8 & IGHA1 & 463 & \\
\hline & Burkitt's lymphoma & 4 & & & 1113339-1113809 \\
\hline bcr 11 & Burkitt`s lymphoma & 4 & IGHE & 416 & $1232681-1233096$ \\
\hline
\end{tabular}

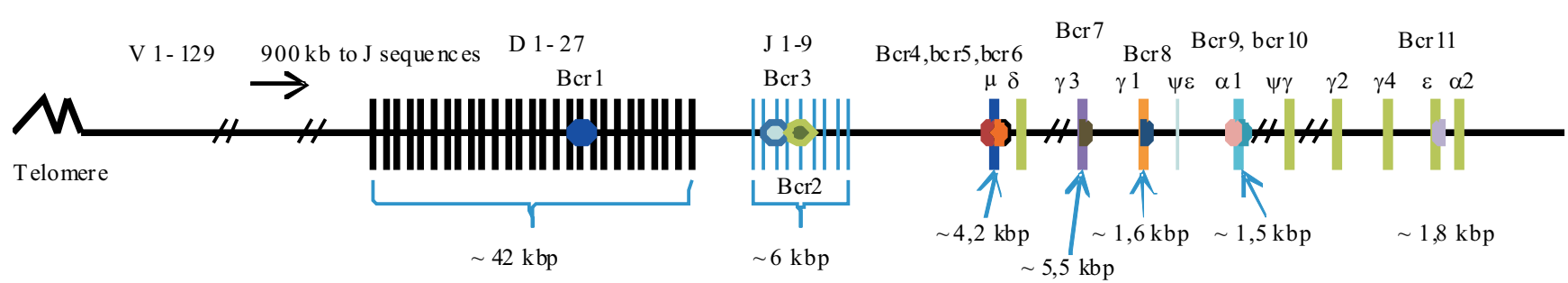

Breakpoint cluster regions in the human immunoglobulin heavy chain gene locus

tion breakpoint sequences in the IgH locus. These were grouped into bcrs, with the condition that one $\sim 1 \mathrm{kbp}$ $b c r$ should include no less than 3 individual translocation events. We could identify eleven bcrs. These data are summarized in Table and Figure.

Mantle cell lymphoma (MCL) is caused by a $t(11$ : 14) involving IgH and CCND1 loci [54]). The translocation is thought to occur during $\mathrm{V}(\mathrm{D}) \mathrm{J}$ recombina- tion [55]. Indeed, most MCL-related breakpoints are located in the JH region. They are concentrated in two bcrs (bcr 2 and bcr 3$)$ in JH regions 2-4 and 4-6 [28, 36, $46,49,50,54,55]$. An additional $b c r(b c r 1)$ is located in the $\mathrm{D}$ region, what is not very characteristic of MCL [49].

$I g H / c-m y c$ translocations ( $\mathrm{t}(8: 14))$ lead to Burkitt's lymphoma (BL) $[42,43]$. These translocations occur 
during somatic hypermutation (SH) [56] or class switch recombination (CSR) [44]. Bcrs for BL thus occur mostly in JH regions [40] and the constant region of the IgH locus, precisely in $\mu, \gamma 3, \alpha 1, \gamma 1$ and $\varepsilon$ genes [40, 43].

The WHSC1 (Wolf-Hirschhorn syndrome) gene located on chromosome 4 is the main $\mathrm{IgH}$ translocation partner in multiple myeloma. This translocation occurs during CSR [34, 57]. Logically, breakpoint regions for multiple myeloma $($ bcrs $4-8,10)$ are localized in the constant region [34, 57].

Diffuse large B-cell lymphoma (DLBCL) is linked to translocations with $C C N D 3$ and $C C N D 4$ genes on chromosome 3 [40]). In general, this translocation occurs during CSR [58] and somatic hypermutation [59]. The $b c r$ for DLBCL $(b c r 7)$ is localized in the $\gamma 2$ gene (constant region).

Interestingly, several bcrs $(b c r 2,4,5-7,10)$ are not specific for one type of cancer. These bcrs are located in the regions that are the subjects to $\mathrm{V}(\mathrm{D}) \mathrm{J}$ recombination (bcr2), CSR (bcr4-8; 10) and SH (bcr2, 4-8, 10). This suggests that these bcrs in the IgH locus are in contact with several different potential translocation partners at the same time. Whether it happens in all B-cells, or there are subsets or individual B-cells where IgH bcrs contact specific partners is not yet known. This question might be answered by using a circular chromosome conformation capture (4C) technique [29] on individual cells and cell populations. The BCRs identified in the present review may serve as convenient baites for this technique. Further studies will be necessary to answer the posed questions.

Funding. This work was supported by Fondation de France grants N 2006008196 , MCEHP, Institute National de Cancer (INCa) PAIRMCL and ERABL and Agence Nationale de Recherche sur le Sida (ANRS) to YV, and 13-04-93105 from RFBR foundation to OI.

Транслокації, обумовлені локусом важкого ланцюга гена імуноглобуліну людини

I. В. Скляр, О. В. Ярова, М. Ліпинський, С. С. Васецький

Резюме

Транслокації за участі локуса важкого ланщюга гена імуноглобулінів відіграють певну роль в онкогенезі багатьох лімфом і лейкемій, серед яких множинна мієлома, лімфома мантійної зони, лімфома Беркітта та дифузна В-клітинна лімфома. На основі аналізу опублікованих даних ми виділили 11 областей, у яких відбуваються транслокачї, що призводять до вищезгаданих лімфом $і$ лейкемій. Кожна з таких областей (розміром приблизно 1000 пар нуклеотидів) може брати участь у транслокачіях, які спричиняють один або декілька типів раку. Отримані результати можна використовувати при розробиі діагностики транслокацій, які викликають рак крові, а також при ідентифікації потенційних транслокаційних партнерів локуса важкого ланиюга гена імуноглобулінів на різних стадіях диференціювання В-лімфоцитів.

Ключові слова: транслокачї, важкий ланцюг імуноглобуліну людини, онкогенез, лімфома, лейкемія, диференціювання В-клітин.

Транслокации, обусловленные локусом тяжелой цепи гена иммуноглобулина человека

И. В. Скляр, О. В. Яровая, М. Липинский, Е. С. Васецкий Резюме

Транслокаџии с участием локуса тяжелой цеепи гена иммуноглобулинов играют определенную роль в онкогенезе многих лимфом и лейкемий, включая множественную миелому, лимфому мантийной зоны, лимфому Беркитта и диффузную В-клеточную лимфому. На основе анализа опубликованных данных мы выделили 11 областей, в которых происходят транслокачии, приводящчие к вышеупомянутым лимфомам и лейкемиям. Каждая из таких областей (размером примерно 1000 пар нуклеотидов) может участвовать в транслокациях, являющихся причиной одного или нескольких типов рака. Полученнье результать можно использовать при разработке диагностики транслокаџий, вызывающих рак крови, а также при идентификации потенциальных транслокационных партнеров локуса тяжелой цеепи гена иммуноглобулинов на разных стадиях дифференцировки В-лимфочитов.

Ключевые слова: транслокации, тяжелая цепь иммуноглобулина человека, онкогенез, лимфома, лейкемия, дифферениировка В-клеток.

\section{REFERENCES}

1. Boveri T. Zur Frage der Entstehung maligner Tumoren. Jena: G. Fisher, 1914; 64 p.

2. Balmain A. Cancer genetics: from Boveri and Mendel to microarrays. Nat Rev Cancer. 2001; 1(1):77-82.

3. Nambiar M, Raghavan SC. How does DNA break during chromosomal translocations? Nucleic Acids Res. 2011; 39(14): 5813-25.

4. Negritto MC. Repairing double-strand DNA breaks. Nature Education. 2010; 3(9):26.

5. Lieber MR. Warner-Lambert/Parke-Davis award lecture. Pathological and physiological double-strand breaks: roles in cancer, aging, and the immune system. Am J Pathol. 1998; 153 (5):1323-32.

6. Maizels N. Immunoglobulin gene diversification. Annu Rev Genet. 2005; 39:23-46.

7. Karanjawala ZE, Hinton DR, Oh E, Hsieh CL, Lieber MR. Developmental retinal apoptosis in $\mathrm{Ku} 86^{--}$mice. DNA Repair (Amst). 2003; 2(12):1429-34.

8. Korsmeyer SJ. Chromosomal translocations in lymphoid malignancies reveal novel proto-oncogenes. Annu Rev Immunol. 1992; 10:785-807.

9. Taub R, Kirsch I, Morton C, Lenoir G, Swan D, Tronick S, Aaronson $S$, Leder $P$. Translocation of the $c$-myc gene into the immunoglobulin heavy chain locus in human Burkitt lymphoma and murine plasmacytoma cells. Proc Natl Acad Sci USA. 1982; 79(24):7837-41. 
10. Mitelman F, Johansson B, Mertens F. Fusion genes and rearranged genes as a linear function of chromosome aberrations in cancer. Nat. Genet. 2004; 36(4):331-4.

11. Harewood L, Schutz F, Boyle S, Perry P, Delorenzi M, Bickmore $W A$, Reymond $A$. The effect of translocation-induced nuclear reorganization on gene expression. Genome Res. 2010; 20(5):554-64.

12. Allinne J, Pichugin A, Iarovaia O, Klibi M, Barat A, Zlotek-Zlotkiewicz E, Markozashvili D, Petrova N, Camara-Clayette V, Ioudinkova ES, Wiels J, Razin SV, Ribrag V, Lipinski M, Vassetzky YS. Perinucleolar relocalization and nucleolin as crucial events in the transcriptional activation of key genes in mantle cell lymphoma. Blood. 2014; DOI:10.1182/blood-2013-06-510511

13. Revy P, Muto T, Levy Y, Geissmann F, Plebani A, Sanal O, Catalan N, Forveille M, Dufourcq-Labelouse R, Gennery A, Tezcan I, Ersoy F, Kayserili H, Ugazio AG, Brousse N, Muramatsu M, Notarangelo LD, Kinoshita K, Honjo T, Fischer A, Durandy A. Activation-induced cytidine deaminase (AID) deficiency causes the autosomal recessive form of the Hyper-IgM syndrome (HIGM2). Cell. 2000; 102(5):565-75.

14. Di Noia JM, Neuberger MS. Molecular mechanisms of antibody somatic hypermutation. Annu Rev Biochem. 2007; 76:1-22.

15. Reth $M$, Radbruch A, Alt F, Honjo T, Alt FW, Neuberger M. Molecular biology of B cells. $1^{\text {st }}$ ed. London: Elsevier. 2004; 600 p.

16. Muramatsu M, Kinoshita K, Fagarasan S, Yamada S, Shinkai Y, Honjo $T$. Class switch recombination and hypermutation require activation-induced cytidine deaminase (AID), a potential RNA editing enzyme. Cell. 2000; 102(5):553-63.

17. Lieber MR. The mechanism of double-strand DNA break repair by the nonhomologous DNA end-joining pathway. Annu Rev Biochem. 2010; 79:181-211.

18. Klein U, Dalla-Favera R. Germinal centres: role in B-cell physiology and malignancy. Nat Rev Immunol. 2008; 8(1):22-33.

19. Yu K, Chedin F, Hsieh CL, Wilson TE, Lieber MR. R-loops at immunoglobulin class switch regions in the chromosomes of stimulated B cells. Nat Immunol. 2003; 4(5):442-51.

20. Peled JU, Kuang FL, Iglesias-Ussel MD, Roa S, Kalis SL, Goodman $M F$, Scharff $M D$. The biochemistry of somatic hypermutation. Annu Rev Immunol. 2008; 26:481-511.

21. Lefranc $M-P$. IGH (Immunoglobulin Heavy) (14q32.33). Atlas Genet Cytogenet Oncol Haematol. 2000; 4(3):278-289.

22. Robbiani DF, Bothmer A, Callen E, Reina-San-Martin B, Dorsett $Y$, Difilippantonio $S$, Bolland DJ, Chen HT, Corcoran AE, Nussenzweig A, Nussenzweig MC. AID is required for the chromosomal breaks in c-myc that lead to c-myc/IgH translocations. Cell. 2008; 135(6):1028-38.

23. Unniraman S, Schatz DG. AID and Igh switch region-Myc chromosomal translocations. DNA Repair (Amst). 2006; 5(9-10): 1259-64.

24. Okazaki IM, Kotani A, Honjo T. Role of AID in tumorigenesis. Adv Immunol. 2007; 94:245-73.

25. Duquette $M L$, Pham P, Goodman MF, Maizels $N$. AID binds to transcription-induced structures in c-MYC that map to regions associated with translocation and hypermutation. Oncogene. 2005; 24(38):5791-8

26. Meissner B, Bartram T, Eckert C, Trka J, Panzer-Grumayer R, Hermanova I, Ellinghaus E, Franke A, Moricke A, Schrauder A, Teigler-Schlegel A, Dorge P, Von Stackelberg A, Basso G, Bartram CR, Kirschner-Schwabe R, Bornhauser B, Bourquin JP, Cazzaniga $G$, Hauer J, Attarbaschi A, Izraeli S, Zaliova M, Cario $G$, Zimmermann $M$, Avigad S, Sokalska-Duhme M, Metzler M, Schrappe M, Koehler R, Te Kronnie G, Stanulla M. Frequent and sex-biased deletion of SLX4IP by illegitimate V(D)J-mediated recombination in childhood acute lymphoblastic leukemia. Hum Mol Genet. 2014; 23(3):590-601.
27. Jardin F, Bastard C, Contentin N, Parmentier F, Picquenot JM, Tilly H, Stevenson FK, Sahota SS. Intronic BCL-6 mutations are preferentially targeted to the translocated allele in $\mathrm{t}(3 ; 14)(\mathrm{q} 27$; q32) non-Hodgkin B-cell lymphoma. Blood. 2003; 102(5): 1872-6.

28. Greisman HA, Lu Z, Tsai AG, Greiner TC, Yi HS, Lieber MR IgH partner breakpoint sequences provide evidence that AID initiates $\mathrm{t}(11 ; 14)$ and $\mathrm{t}(8 ; 14)$ chromosomal breaks in mantle cell and Burkitt lymphomas. Blood. 2012; 120(14):2864-7.

29. van de Werken HJ, de Vree PJ, Splinter E, Holwerda SJ, Klous $P$, de Wit $E$, de Laat $W$. 4C technology: protocols and data analysis. Methods Enzymol. 2012; 513:89-112.

30. Akasaka T, Balasas T, Russell LJ, Sugimoto KJ, Majid A, Walewska R, Karran EL, Brown DG, Cain K, Harder L, Gesk S, Martin-Subero JI, Atherton MG, Bruggemann M, Calasanz MJ, Davies $T$, Haas $O A$, Hagemeijer A, Kempski H, Lessard M, Lillington DM, Moore S, Nguyen-Khac F, Radford-Weiss I, Schoch C, Struski S, Talley P, Welham MJ, Worley H, Strefford JC, Harrison $C J$, Siebert $R$, Dyer $M J$. Five members of the CEBP transcription factor family are targeted by recurrent IGH translocations in B-cell precursor acute lymphoblastic leukemia (BCPALL). Blood. 2007; 109(8):3451-61.

31. Kawamata N, Nakamura Y, Miki T, Sato E, Isobe Y, Furusawa $S$, Hirosawa $S$, Oshimi $K$. Detection of chimaeric transcripts of the immunoglobulin heavy chain and BCL6 genes by reversetranscriptase polymerase chain reaction in B-cell non-Hodgkin's lymphomas. Br J Haematol. 1998; 100(3):484-9.

32. Sonoki T, Harder L, Horsman DE, Karran L, Taniguchi I, Willis TG, Gesk S, Steinemann D, Zucca E, Schlegelberger B, Sole F, Mungall AJ, Gascoyne RD, Siebert R, Dyer MJ. Cyclin D3 is a target gene of $\mathrm{t}(6 ; 14)(\mathrm{p} 21.1 ; \mathrm{q} 32.3)$ of mature B-cell malignancies. Blood. 2001; 98(9):2837-44.

33. Chesi M, Bergsagel PL, Brents LA, Smith CM, Gerhard DS, Kuehl WM. Dysregulation of cyclin D1 by translocation into an $\mathrm{IgH}$ gamma switch region in two multiple myeloma cell lines. Blood. 1996; 88(2):674-81.

34. Fenton JA, Pratt G, Rawstron AC, Sibley K, Rothwell D, Yates Z, Dring A, Richards SJ, Ashcroft AJ, Davies FE, Owen RG, Child $J A$, Morgan GJ. Genomic characterization of the chromosomal breakpoints of $\mathrm{t}(4 ; 14)$ of multiple myeloma suggests more than one possible aetiological mechanism. Oncogene. 2003; 22(7): $1103-13$.

35. Kobayashi S, Taki T, Chinen Y, Tsutsumi Y, Ohshiro M, Kobayashi T, Matsumoto Y, Kuroda J, Horiike S, Nishida K, Taniwaki $M$. Identification of IGHCdelta-BACH2 fusion transcripts resulting from cryptic chromosomal rearrangements of $14 \mathrm{q} 32$ with $6 \mathrm{q} 15$ in aggressive B-cell lymphoma/leukemia. Genes Chromosomes Cancer. 2011; 50(4):207-16.

36. Degan $M$, Doliana $R$, Gloghini A, Di Francia $R$, Aldinucci D, Mazzocut-Zecchin L, Colombatti A, Attadia V, Carbone A, Gattei $V$. A novel bcl-1/JH breakpoint from a patient affected by mantle cell lymphoma extends the major translocation cluster. $J$ Pathol. 2002; 197(2):256-63.

37. Moulding C, Rapoport A, Goldman P, Battey J, Lenoir GM, Le$\operatorname{der} P$. Structural analysis of both products of a reciprocal translocation between c-myc and immunoglobulin loci in Burkitt lymphoma. Nucleic Acids Res. 1985; 13(6):2141-52

38. Gutierrez MI, Bhatia K, Barriga F, Diez B, Muriel FS, De Andreas $M L$, Epelman $S$, Risueno $C$, Magrath $I T$. Molecular epidemiology of Burkitt's lymphoma from South America: differences in breakpoint location and Epstein-Barr virus association from tumors in other world regions. Blood. 1992; 79(12):3261-6.

39. Siebert R, Matthiesen P, Harder S, Zhang Y, Borowski A, Zuhlke-Jenisch R, Metzke S, Joos S, Weber-Matthiesen K, Grote W, 
Schlegelberger B. Application of interphase fluorescence in situ Hybridization for the detection of the Burkitt translocation $\mathrm{t}(8$ 14)(q24;q32) in B-cell lymphomas. Blood. 1998; 91(3):984-90.

40. Busch K, Borkhardt A, Wossmann W, Reiter A, Harbott J. Combined polymerase chain reaction methods to detect c-myc/IgH rearrangement in childhood Burkitt's lymphoma for minimal residual disease analysis. Haematologica. 2004; 89(7):818-25.

41. Muller JR, Janz S, Potter M. Differences between Burkitt's lymphomas and mouse plasmacytomas in the immunoglobulin heavy chain/c-myc recombinations that occur in their chromosomal translocations. Cancer Res. 1995; 55(21):5012-8.

42. Neri A, Barriga F, Knowles DM, Magrath IT, Dalla-Favera $R$. Different regions of the immunoglobulin heavy-chain locus are involved in chromosomal translocations in distinct pathogenetic forms of Burkitt lymphoma. Proc Natl Acad Sci USA. 1988; 85 (8):2748-52.

43. Busch K, Keller T, Fuchs U, Yeh RF, Harbott J, Klose I, Wiemels $J$, Novosel A, Reiter A, Borkhardt A. Identification of two distinct MYC breakpoint clusters and their association with various IGH breakpoint regions in the $\mathrm{t}(8 ; 14)$ translocations in sporadic Burkitt-lymphoma. Leukemia. 2007; 21(8):1739-51.

44. Guikema JE, De Boer C, Haralambieva E, Smit LA, Van Noesel CJ, Schuuring E, Kluin PM. IGH switch breakpoints in Burkitt lymphoma: exclusive involvement of noncanonical class switch recombination. Genes Chromosomes Cancer. 2006; 45(9): $808-19$.

45. Wilda M, Busch K, Klose I, Keller T, Woessmann W, Kreuder J, Harbott $J$, Borkhardt A. Level of MYC overexpression in pediatric Burkitt's lymphoma is strongly dependent on genomic breakpoint location within the MYC locus. Genes Chromosomes Cancer. 2004; 41(2):178-82.

46. Siebert R, Matthiesen P, Harder S, Zhang Y, Borowski A, Zuhlke-Jenisch R, Plendl H, Metzke S, Joos S, Zucca E, Weber-Matthiesen K, Roggero E, Grote W, Schlegelberger B. Application of interphase cytogenetics for the detection of $\mathrm{t}(11 ; 14)(\mathrm{q} 13 ; \mathrm{q} 32)$ in mantle cell lymphomas. Ann Oncol. 1998; 9(5):519-26.

47. Andersen NS, Donovan JW, Borus JS, Poor CM, Neuberg D, Aster JC, Nadler LM, Freedman AS, Gribben JG. Failure of immunologic purging in mantle cell lymphoma assessed by polymerase chain reaction detection of minimal residual disease. Blood. 1997; 90(10):4212-21.

48. Ronchetti D, Finelli P, Richelda R, Baldini L, Rocchi M, Viggiano L, Cuneo A, Bogni S, Fabris S, Lombardi L, Maiolo AT, Neri A. Molecular analysis of $11 \mathrm{q} 13$ breakpoints in multiple myeloma. Blood. 1999; 93(4):1330-7.

49. Welzel N, Le T, Marculescu R, Mitterbauer G, Chott A, Pott C, Kneba M, Du MQ, Kusec R, Drach J, Raderer M, Mannhalter C, Lechner K, Nadel B, Jaeger U. Templated nucleotide addition and immunoglobulin JH-gene utilization in $\mathrm{t}(11 ; 14)$ junctions: implications for the mechanism of translocation and the origin of mantle cell lymphoma. Cancer Res. 2001; 61(4):1629-36.
50. Murga Penas EM, Callet-Bauchu E, Ye H, Gazzo S, Berger F, Schilling G, Albert-Konetzny N, Vettorazzi E, Salles $G$, Wlodarska I, Du MQ, Bokemeyer C, Dierlamm J. The t(14;18)(q32; q21)/IGH-MALT1 translocation in MALT lymphomas contains templated nucleotide insertions and a major breakpoint region similar to follicular and mantle cell lymphoma. Blood. 2010; 115(11):2214-9.

51. Tsai $A G$, Lu Z, Lieber MR. The t(14;18)(q32;q21)/IGH-MALT1 translocation in MALT lymphomas is a CpG-type translocation, but the $\mathrm{t}(11 ; 18)(\mathrm{q} 21 ; \mathrm{q} 21) / \mathrm{API} 2-\mathrm{MALT} 1$ translocation in MALT lymphomas is not. Blood. 2010; 115(17):3640-1.

52. Jaeger U, Purtscher B, Karth GD, Knapp S, Mannhalter C, Lechner $K$. Mechanism of the chromosomal translocation $t(14 ; 18)$ in lymphoma: detection of a $45-\mathrm{Kd}$ breakpoint binding protein. Blood. 1993; 81(7): 1833-40.

53. Butler MP, Iida S, Capello D, Rossi D, Rao PH, Nallasivam $P$, Louie DC, Chaganti S, Au T, Gascoyne RD, Gaidano G, Chaganti $R S$, Dalla-Favera $R$. Alternative translocation breakpoint cluster region 5' to BCL-6 in B-cell non-Hodgkin's lymphoma. Cancer Res. 2002; 62(14):4089-94.

54. Rimokh R, Berger F, Delsol G, Digonnet I, Rouault JP, Tigaud JD, Gadoux M, Coiffier B, Bryon PA, Magaud JP. Detection of the chromosomal translocation $\mathrm{t}(11 ; 14)$ by polymerase chain reaction in mantle cell lymphomas. Blood. 1994; 83(7):1871-5.

55. Stamatopoulos K, Kosmas C, Belessi C, Kyriazopoulos P, Papadaki T, Anagnostou D, Loukopoulos D. Molecular analysis of bcl-1/IgH junctional sequences in mantle cell lymphoma: potential mechanism of the $\mathrm{t}(11 ; 14)$ chromosomal translocation. Br J Haematol. 1999; 105(1):190-7.

56. Harris RS, Croom-Carter DS, Rickinson AB, Neuberger MS. Epstein-Barr virus and the somatic hypermutation of immunoglobulin genes in Burkitt's lymphoma cells. J Virol. 2001; 75(21): 10488-92.

57. Gabrea A, Leif Bergsagel P, Michael Kuehl W. Distinguishing primary and secondary translocations in multiple myeloma. DNA Repair (Amst). 2006; 5(9-10):1225-33.

58. Lenz G, Nagel I, Siebert R, Roschke AV, Sanger W, Wright GW, Dave SS, Tan B, Zhao H, Rosenwald A, Muller-Hermelink HK, Gascoyne RD, Campo E, Jaffe ES, Smeland EB, Fisher RI, Kuehl $W M$, Chan WC, Staudt LM. Aberrant immunoglobulin class switch recombination and switch translocations in activated B cell-like diffuse large B cell lymphoma. $J$ Exp Med. 2007; 204 (3):633-43.

59. Khodabakhshi AH, Morin RD, Fejes AP, Mungall AJ, Mungall KL, Bolger-Munro M, Johnson NA, Connors JM, Gascoyne RD, Marra MA, Birol I, Jones SJ. Recurrent targets of aberrant somatic hypermutation in lymphoma. Oncotarget. 2012; 3(11): 1308-19.

Received 15.01.14 